\title{
シャルピ一衝撃試験片と実大破壊部材の破面相関 \\ FRACTOGRAPHIC CORRELATION BETWEEN CHARPY SPECIMENS AND FULL-SCALE MEMBERS
}

\author{
桑 村 仁*，伊山潤** \\ Hitoshi KUWAMURA and Jun IYAMA
}

\begin{abstract}
Charpy impact test has been widely used for inspecting fracture toughness of steels in the world since the 1901 invention by French professor Dr. Georges Charpy. However, there has been a doubt and criticism, especially from fracture mechanics, that Charpy properties such as absorbed energy and percent brittle fracture deduced from the impact test may not be correlated with the fracture performance of actual steel members, because of crucial differences between them in terms of loading rate, specimen size, notch configuration, and stress-strain conditions. However, this paper shows that the surfaces as well as processes of the fractures are remarkably correlated between them, which suggests that Charpy test results can be rationally used as good indices for fracture resistance of structural steel members.
\end{abstract}

Keywords : structural steel, fracture, fractography, Charpy impact test, full-scale test 構造用鋼材，破壊，破面解析，シャルピ一衝撃試験，実大破壊試験

\section{1.はじめに}

1995年兵庫県南部地震において，わが国の震災史上初めて建築鉄

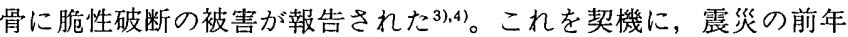
1994年に制定された建築構造用圧延鋼材 (SN 鋼)のシャルピー値を 見直す必要が出てきた5)。もちろん，この SN 鋼が震災で被害を受け たわけではないが，建築構造用鋼材に付与すべき破壊靶性のレベル を造船や海洋構造など他分野の仕様のスライド適用ではなく建築構 造固有の利用状況に基づいて合理的に決めなければならないという 必要に迫られているからである。この中で, シャルピ一值というも のが建築鉄骨構造の破壊性能評価に対していかなる意味をもつかを 明らかにしなければならない状況になっている。

本論では, その手始めとして, 実大構造物の破面形状とシャルピー 衝撃試験片の破面形状について分析し，両者にどのような相関があ るかを調べた。もし，両者の破面形態に相関が無ければシャルピー 衝撃試験を実大構造物の破壞問題に結び付ける技術的根拠が失われ る。逆に，良い相関があればシャルピー衝撃試験を鋼構造分野で有 効利用する合理性が得られることになる。

\section{2. シャルピー衝撃試験の工業的意義と破壊力学的批判}

1901年にフランス人 Charpyによって考案されたシャルピー衝撃

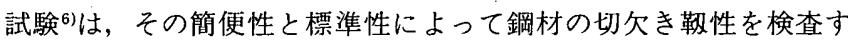
る方法として世界に普及している。しかし，シャルピ一衝撃試験か ら得られる吸収エネルギーや脆性破面率が実大構造物の破壊性能と どのような関係があるかについては未だよく分かっていない。むし
ろ両者には，載荷速度，サイズ，切欠き形状，応力一Uずみ状態に 大きな隔たりがあるので，シャルピ一試験結果から実大構造物の破 壊性能を評価することには無理があるという意見が多い。特に，破 壊力学の研究者は, シャルピー試験結果を実大構造物の破壊性能に 直接結び付けることに対して否定的である。

船舶や海洋構造物，橋梁，圧力容器などの分野では，実大構造物 の破壊性能の評価に破壊力学を用いているが，建築構造の分野では その習慣がない。破壊力学は，完全脆性材料の破壊条件を見い出し た Griffithー1921年7)以来発展を遂げてきた学問分野である。当初の Griffith 理論は, Irwin一1948年8)と Orowan-1949年"9よよって破壊 面の形成への塑性ひずみエネルギーの笴与分を組み入れて補正さ

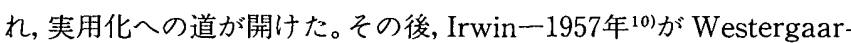
$\mathrm{d}-1939$ 年 ${ }^{11}$ の応力関数に基づいてき裂先端の応力場の解を導いて 以来精力的な研究が行われ，弾性範囲あるいは小規模降伏を伴う領 域での破壊を対象とする線形破壊力学が応力拡大係数というパラ メー夕を用いて確立された。さらに近年，鋼材の切欠き靱性が向上 してきたことに伴い，大きな塑性変形を伴う場合も扱える非線形破 壊力学へと発展を遂げている。このような破壊力学の知見に基づい て, 材料の必要靶性が破壊力学パラメータである応力拡大係数 $K$, き裂先端開口変位 CTOD，J積分， Rカーブなどで規定されるよう になっている12)。

しかしここのうな破壊力学パラメータを用いて材料特性を定め るための試験方法は, 米国の ASTM, 英国の BS，日本のWESなど に見られるように, 試験片形状寸法の制約, 疲労予き裂の導入, 荷
本論文は，参考文献1）,2)に基ついてまとめたものである。

* 東京大学工学部総合試験所 助教授・Ph. D

** 東京大学工学部総合試験所 助手・修( (I)
Assoc. Prof., Eng. Res. Inst., School of Eng., the Univ. of Tokyo, Ph. D. Res. Assoc., Eng. Res. Inst., School of Eng., the Univ. of Tokyo, M. Eng. 
重と変形の関係を求める手順などのため, かなり面倒であり工業的 試験方法としては適さない。このようなことから, 破壊力学の学術 的発展にもかかわらず依然としてシャルピ一衝撃試験が工業生産の 現場で使われている。特に，大量安価に社会に提供されなければな らない建築用鋼材については, 工業的な観点から今後もシャルピー 衝撃試験が破壊勒性の検查方法として用いられることになるである $j^{13)}$ 。

破壊力学がシャルピー試験を疎んじた最大の原因は，その形状寸 法に破壊力学的根拠が無いということよりも, むしろ, シャルピー 試験片には切欠きは有ってもき裂が無いということである。切欠き (ノッチ) は先端の曲率が有限で，き裂（クラック）は先端の曲率が 無限大であり，両者はその先端で力学的にまったく異なる不連続性 を呈する。破壊力学は, き裂が予め存在することがその理論展開の 前提であるため, 予き裂の無いシャルピー試験片は破壊力学では扱

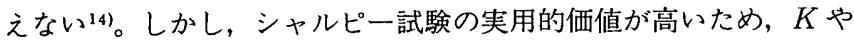
CTOD どの破壞力学パラメータとシャルピー值との相関に関す る研究が精力的に行われ, 両者には工学的に有意な相関があるとさ れている ${ }^{12)}$ 。その結果, 皮肉にも破壊力学的アプロ一チそのものの実 用的意義が薄れている状況とも言える。

今世紀，鉄骨構造の重要な課題であった座屈現象における耐力や 変形能力を簡便な材料引張試験から得られる降伏強さなどの基本特 性から定量化することに成功したように，もう一つの課題である破 壊現象を簡便なシャルピー試験に基づいて定量化することが鉄骨構 造の分野で求められている。

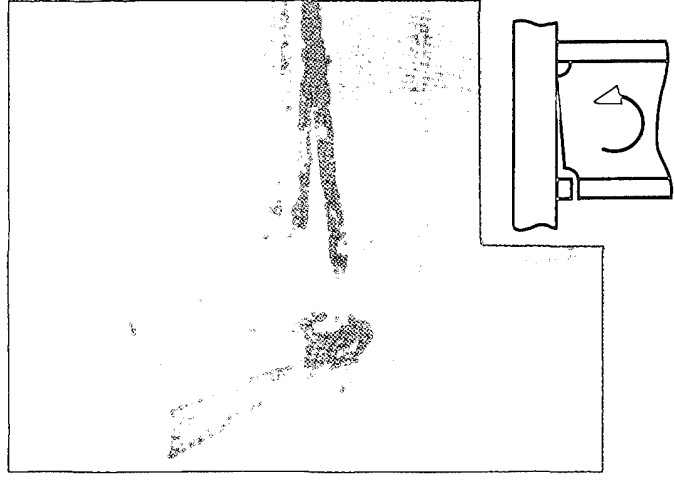

（1）外観

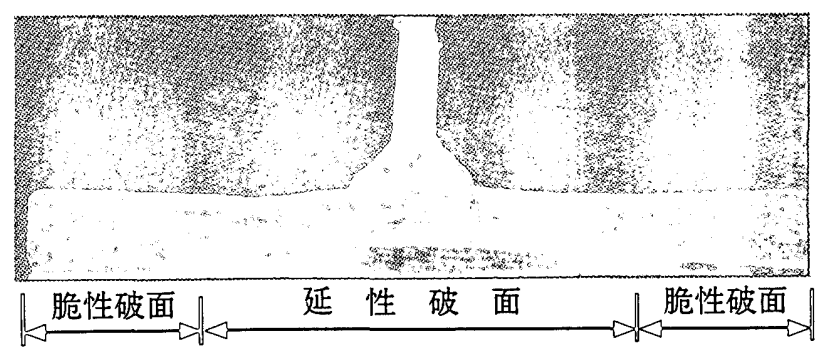

（2）マクロ破面

写真ー 1 梁フランジのスカラップ底破断 ${ }^{18)}$

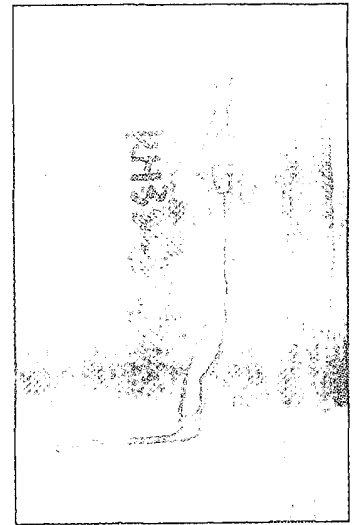

(1) 外観

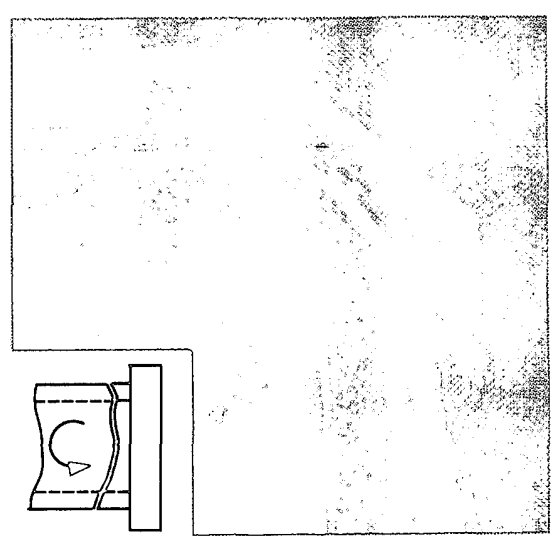

(2) 角部のマクロ破面

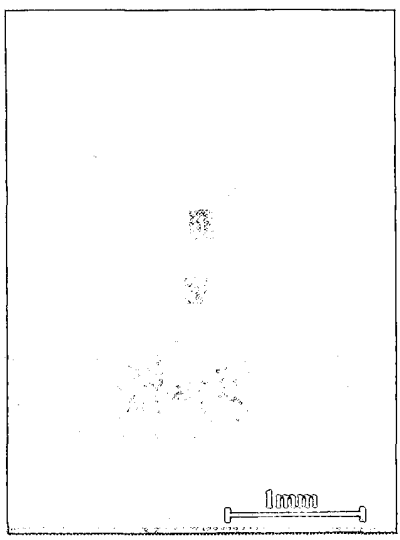

（3）破壊起点の延性一脆性遷 移ミク口破面

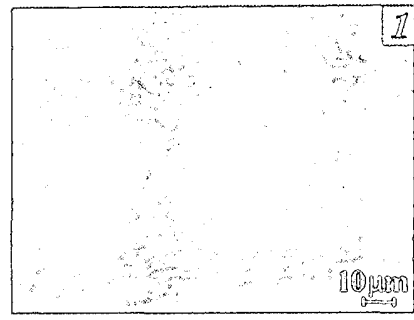

（4）破壊起点の延性ミクロ破面 (ディンプル模様)

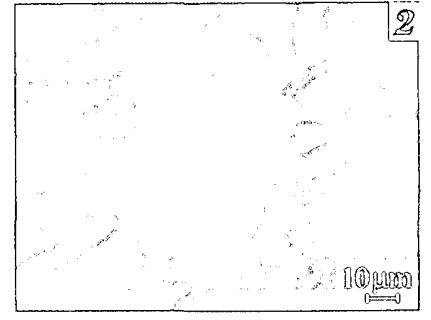

（5）破壊起点の脆性ミク口破面 (リバー模様)

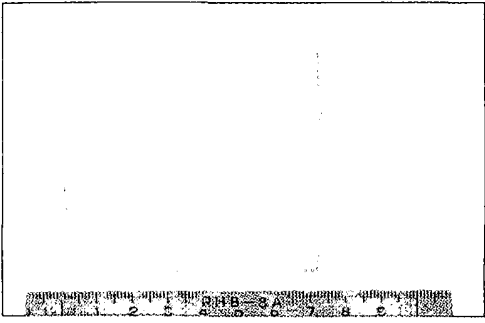

(6) 破断部の断面マクロ組織

写真－2 角形鋼管の通しダイアフラム仕口破断 ${ }^{161}$ 


\section{3．建築鉄骨における脆性破断の実態}

建築鉄骨の脆性破断のプロセスは次の3 段階で構成されてい $3^{15)}$ 。

第 1 段階：延性き裂の発生

第 2 段階：延性き裂の成長

第 3 段階：脆性破壊への転化

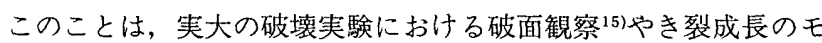
ニタリング16)，および阪神・淡路大震災で破断した鉄骨の破面調 查4),17によって確認されている。それらのうち代表的な鉄骨破断と して,(1)梁フランジのスカラップ底破断 ${ }^{18)}$, (2)角形鋼管の通しダイア フラム仕口破断 ${ }^{16)},(3)$ 柱フランジの球根状剥離破断 ${ }^{18)}$, および(4)神戸 の被災建物における梁フランジ破断 ${ }^{4} の 4$ 種類を写真一 $1 ， 2 ， 3$ ， 4 に掲載する。

写真一 1 は, 溶接組立 $\mathrm{H}$ 形梁がその端部仕ロでスカラップ底から フランジ破断したものである。スカラップ底に発生した延性き裂が 十分成長しフランジ板を貫通してから脆性破壊に転化している。こ の場合は，延性き裂が脆性破断の原因であることが明瞭である。

写真一 2 は，冷間成形角形鋼管が通しダイフラムとの溶接仕口で 脆性破断したものである。角部の外側表面の溶接止端に発生した延 性き裂が 1 ミリ程度の深さまで成長した後, 脆性破壊に転化してい る。それは，電子顕微鏡によるミクロ写真(3)，(4)，(5)において，延
性破面から脆性破面への遷移が見られ，延性破面側にばそれを示す ディンプル模様が見られ，その前方にある脆性破面側にはそれを示 すリバ一模様が観察されることから明らかである。なお，写真(6)の 非破断側を見るとわかるように，溶接止端は丁寧に仕上げられてあ ク予き裂は存在しない。塑性ひずみの負荷によって延性き裂が生ま れ，成長し，それが脆性破壊の引き金になるのである。予き裂とい う久陷の存在を前提とする破壊力学では建築鉄骨の脆性破断の問題 を解くことはできない。

写真一 3 は，溶接組立箱形断面柱のフランジが，突合せ溶接され た梁フランジから作用する板厚方向引張力によって剥離破断したも のである。写真(2)の破面の目視観察だけでは全断面脆性破面のよj に見える。しかし, 破壊の起点となっている裏当て金への初層溶接 ビードのルート部を SEM で観察するとやはり，写真(4)に示すよう に破壊起点には延性き裂が先行発生したことを示すディンプル模様 が認められる。

写真一 4 は，兵庫県南部地震で実際に被災した建物から採取した 破面である。これは圧延 $\mathrm{H}$ 形鋼梁が端部仕ロでスカラップ底からフ ランジ破断したものであり，兵庫県南部地震でたくさん報告された 被害である。目視観察によると，全断面脆性破面のように見えるが， SEM で調べると，この場合もやはり写真(3)にあるように破壊起点 のウェブフィレット部に延性き裂を示すディンプルがある。

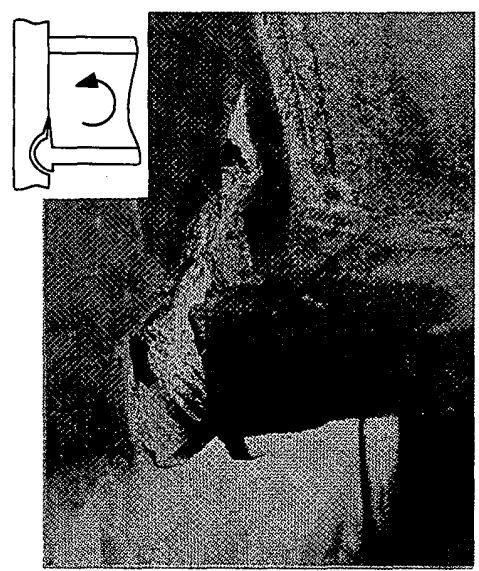

(1) 外観

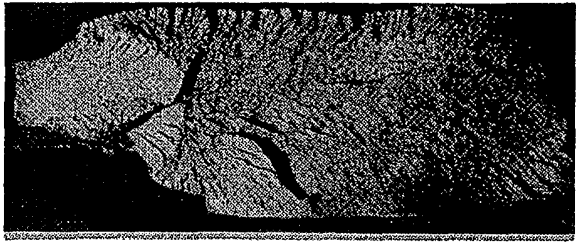

（2）全体マク口破面

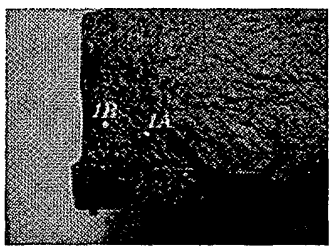

（3）破壊起点のマク口破面

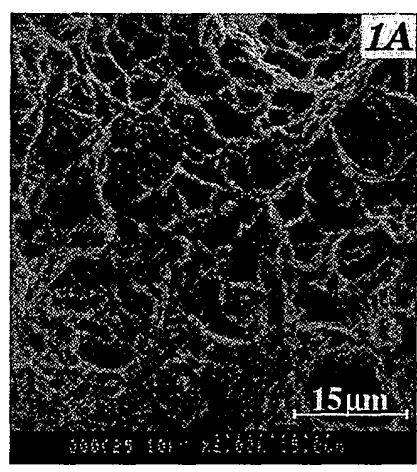

（4）破堎起点の延性ミク口破面 (ディンプル模様)

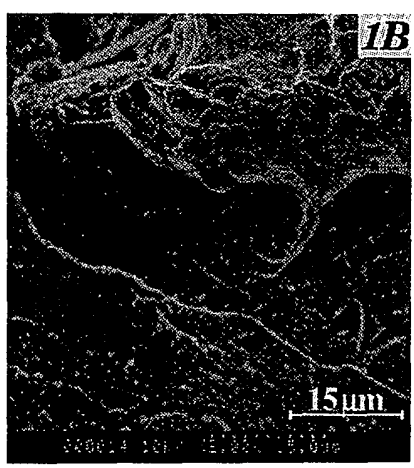

（5）破壊起点の脆性ミク口破面 (リバー模様)

写真一 3 柱フランジの球根状剝離破断 18 


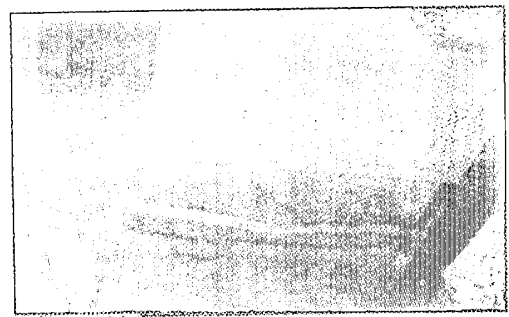

（1）外観

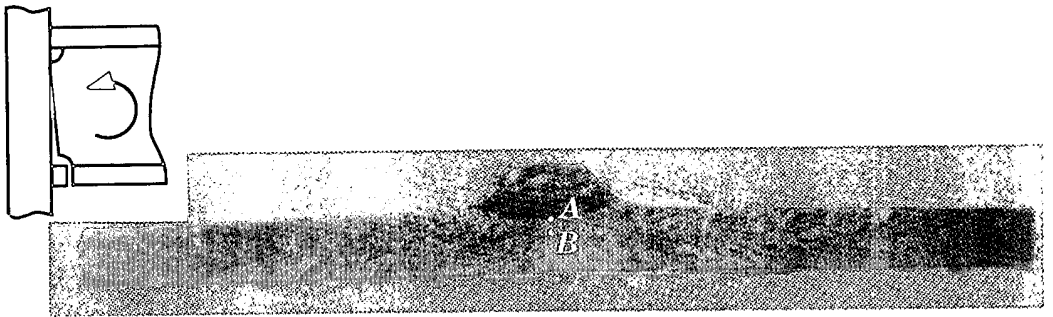

(2) 全体マク口破面

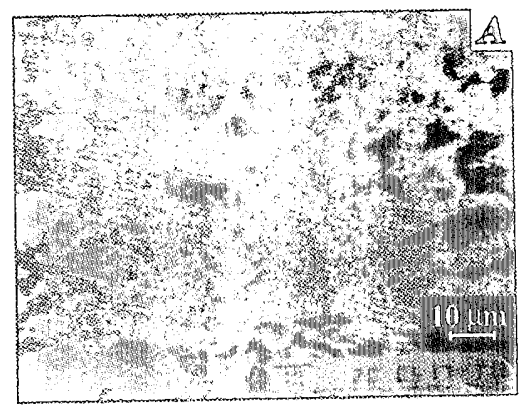

（3）破壊起点の延性ミク口破面 (ディンプル模様)

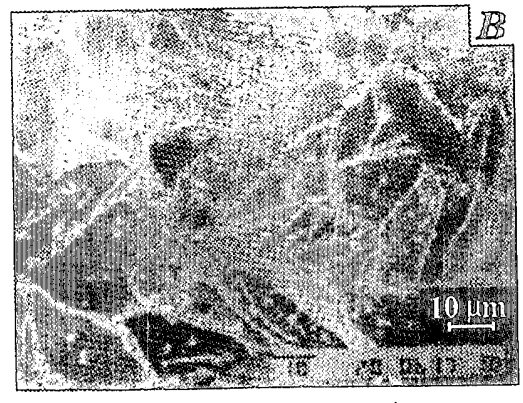

（4）破壞起点の脆性ミク口破面

(リバー模様)

写贡一－4神戸の被災建物における梁フランジ破断4)

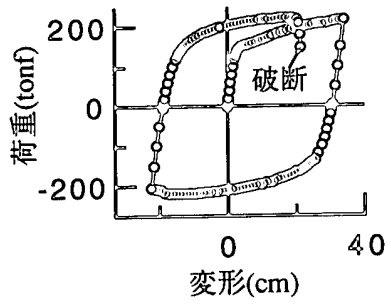

(1) 写真一 1 の試験体 ${ }^{18)}$

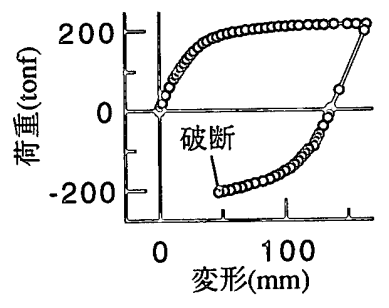

(2) 写真-2 の試験体 ${ }^{16)}$

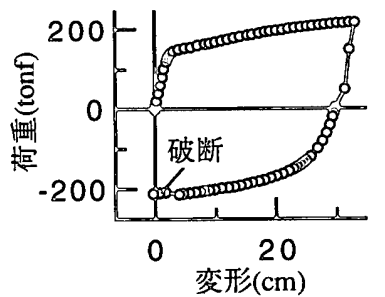

(3) 写真一 3 の試験体 ${ }^{18)}$

図一1 破壞試験から得られた荷重と変形の関係

以上のように, 鉄骨の破断は場所によって様々な外観を呈するが, 破壇起点を SEM で詳細に調べると, 必ず, 脆性破面に先行して延性 き裂を示すディンプルが確認できる。つまり，建築鉄骨に脆性破断 が起きるときには, 延性き裂がサイズの大小は別にして必ず先行発 生し，それが脆性破断の引き金になる。

以上のうち, 実験室で静的加力により再現された最初の 3 ケース について，破断するまでの荷重と変形の関係を図一1(1)，(2)，(3)に 示す。これらの図から分かるように，脆性破断に至るまでかなりの 塑性変形を経ており，Uずみ集中域にある破壊起点においては相当 大きな塑性Uずみが発生し, 材料の延性限界を突破して, 延性き裂 の発生と成長を促すことが容易に想像される。

\section{4. シャルピー衛踇試験における破面}

試験温度を変化させて得られるシャルピ一遷移線図の一例を図 -2に示す。これは文献19)から引用した冷間成形角形鋼管角部の データである。遷移曲線の下部棚，遷移域の下部と上部，および上 部棚の 4 力所のポイント，それぞれー $40,-20, \pm 0,+20^{\circ} \mathrm{C} に お ~$
けるシャルピー衝撃試験片のマクロ破面を写真一 5 の左列に示 す。 $-40^{\circ} \mathrm{C}$ における脆性破面率は $100 \%$ と判定され,ノッチ底におけ

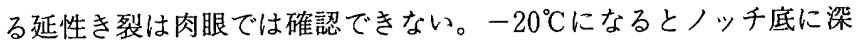
さが十分の数ミリ程度の延性き裂が目視観察される。さらに温度が

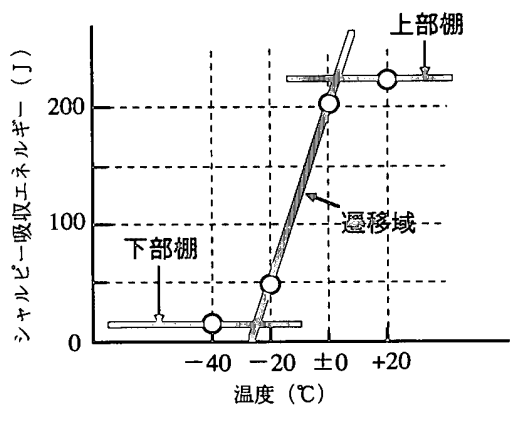

冈ー2 シャルピー遷移線図 
上昇すると, 脆性破面率は低下し， $+20^{\circ} \mathrm{C} て ゙ は 100 \%$ 延性破面になっ ている。

次に，これらの破面のノッチ底直下を SEM で観察したものが写 真一 5 の右列に示されている。写真はマク口破面と同じ向きになっ ており, 破壊が各写真の右から左に進行している。ここで注目すべ き重要なことは，目視では全断面脆性破面と見られたー $40^{\circ} \mathrm{C}$ 試験片 においてさえ，ノッチ底に延性き裂を示すディンプルが媣さ数十ミ クロンの範囲に認められることである。これは, 前章で述べた実際 の鉄骨破断で，全断面脆性破面と見られた破面の破壊起点に延性き 裂の先行発生を示すディンプルが存在していたことと対応してい る。

このようにシャルピー衝撃試験片の破面は，下部棚の全断面脆性 破面の温度域にあっても，ノッチ底に発生し成長した延性き裂が引 き金となって脆性破壊が伝播するという形態になっており，これは 前章で示した実大構造物の破面と全く同じである。また，温度の低 下に伴い材料の破壊勒性が低下すると，ノッチ底に先行発生する延 性き裂が極めて浅い成長段階で脆性破壊に転化することがシャル ピ一試験片の破面分析から分かる。この傾向は実大構造物において も観察されている ${ }^{16)}$ 。

\section{5 . 実大構造物とシャルピー試験片の破面比較}

実大破壊試験の破面とそれと同一の鋼材から製作したシャルピー 試験片の破面を比較してみる。実大破壊試験のデ一夕は文献20)から 引用しだものである。

まず，実大破壊試験における脆性破断の様子を写真一 6 に示す。 このうち写真(1)に示すように，破壊は幅に段差の付いたフランジの アール止端に設けた切欠きから発生している。この切欠きは深さが $1 \mathrm{~mm}$, 角度が $30^{\circ}$ で, 先端半径はシャルピー試験片と同じ $0.25 \mathrm{~mm}$ で ある。破壊は起点と反対側の縁に伝播し $40 \mathrm{~mm}$ 厚のフランジが完全

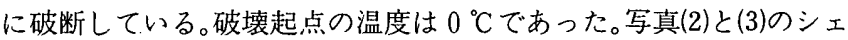
ブロン模様の源をたどると，破壊の起点は板厚中央のノッ千底であ ることがわかる。肉眼では全断面脆性破面のように見えるが, SEM によると写真(4)にあるようにノッチ底から0.1mmオーダ一の媣さ の延性き裂が確認できる。この部分は写真(5)のディンプル破面であ り，その左前方は写真(6)のリバー破面である。

この試験体が破断に至るまでの荷重と変形の関係を図一 3 に示 す。一方向の静的載荷で破断しているが，破断までにかなりの塑性 変形を示している。破断時の変形を全塑性変形で除した塑性率は 5 である。

次に，図一 4 に示すように，この奏大破壊試験体と同じ鋼材から， 実大試験で破壊の起点となったと同じ位置（板厚中央）かつ同じ方 向にシャルピー試験片を採取して，同じ温度 $\left(0{ }^{\circ} \mathrm{C}\right)$ で衙撃試験を 実施した。その破面の様子を写真一 7 に示す。実大破壊試験の破面 と同様，肉眼では脆性破面率が $100 \%$ と判定されるが，SEMによる と切欠き底に脆性破面に先行する延性破面がノッ千底から $0.1 \mathrm{~mm}$ 程度の染さの範囲に観察される。このシャルピ一破面を前出写真 一 6 の実大試験体の破面と比較すると，延性破面から脆性破面への 遷移状態がそっくりである。

次に、レーザー顕微鏡を用いて上記の実大試験体破面とシャル ピ一破面の凹凸形状を測定した。各々の試料のディンプル部分とリ
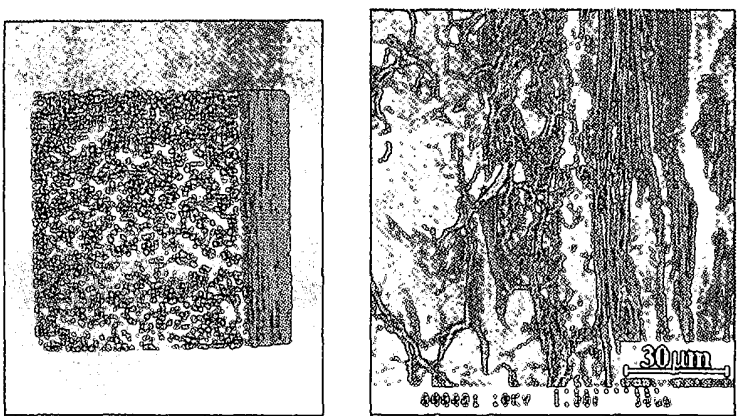

(1) $-40^{\circ} \mathrm{C}$ (下部棚)
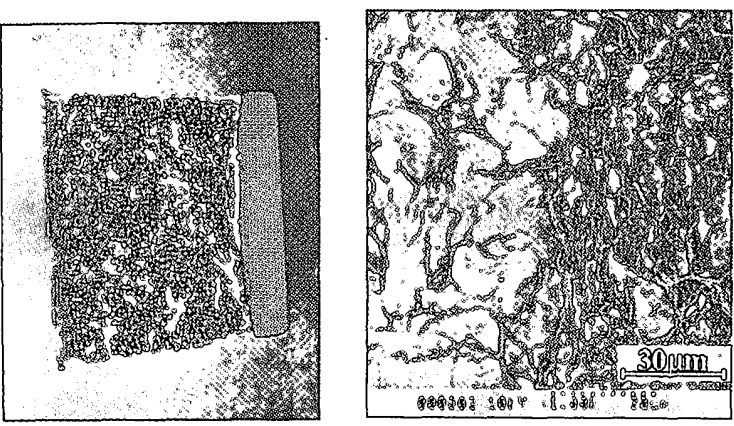

(2) $-20^{\circ} \mathrm{C}$ (遷移域の下部)
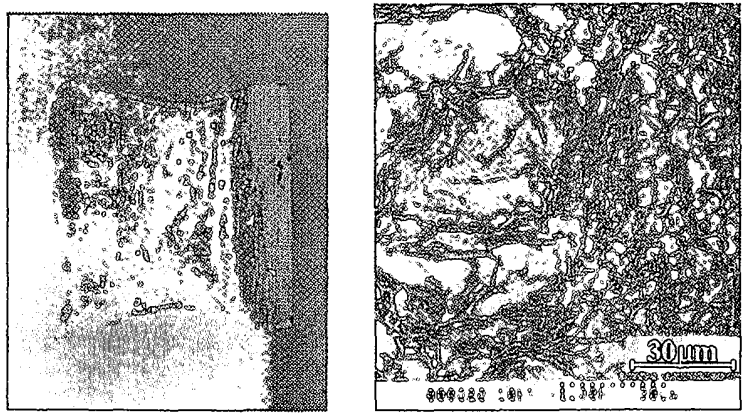

(3) $\pm 0{ }^{\circ} \mathrm{C}$ (遷移域の上部)
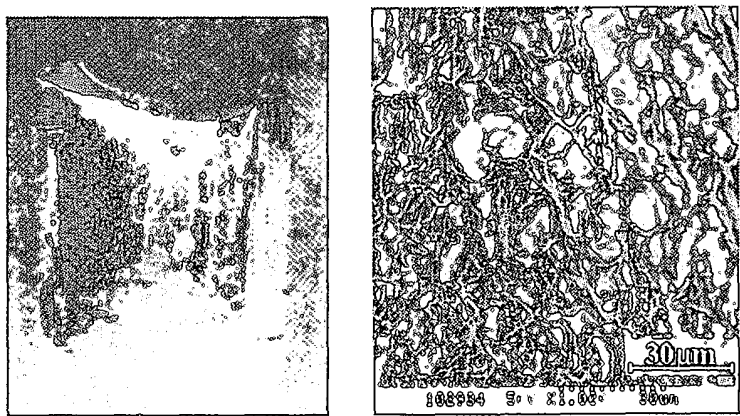

(4) $+20^{\circ} \mathrm{C}$ (上部棚)

写真一 5 シャルピー衝撃試験片のマクロおよU゙ミクロ破面 （左：マクロ破面，右：ノッチ底ミク口破面）

バー部分が写真一 8(1) (4)に揭載されている。各写真において, 左 右の〉とবを結ぶライン上で表面起伏が測定されており，2本の縦 線の間が測定区間 (間隔 $x=20$ ミクロン), 2 本の横線が最高および 最低の高さレベルを指しており，その間隔 $z$ が高低差となる。これ 


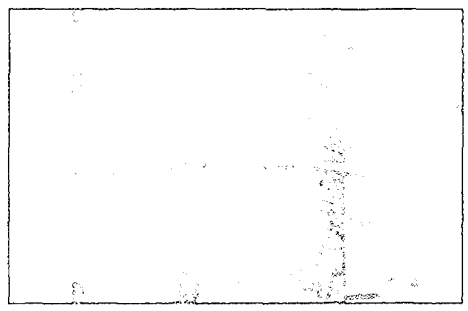

（1）外観

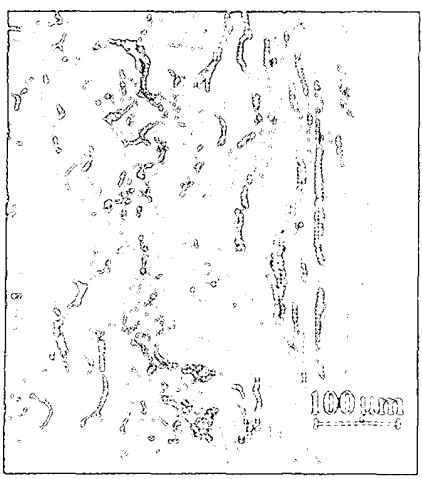

（4）ノッチ底の延性一脆性遷 移ミク口破面

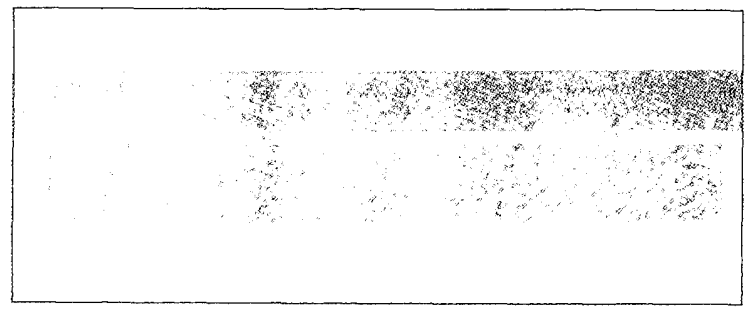

（2）全体のマクロ破面

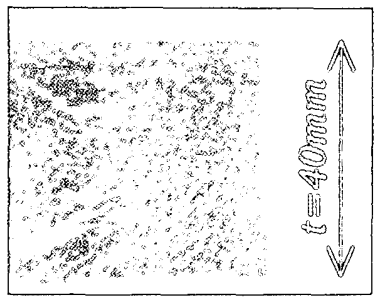

（3）破壊起点のマクロ破面

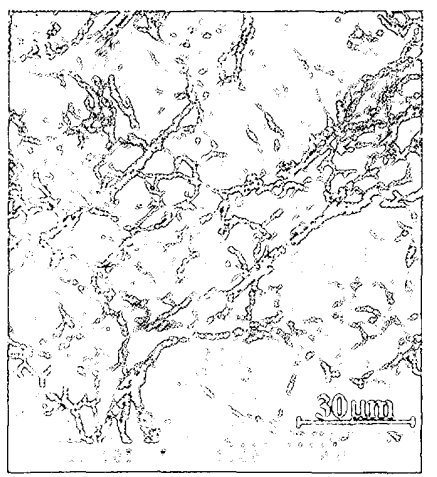

（5）破壊起点の延性ミク口破面 (ディンプル模様)

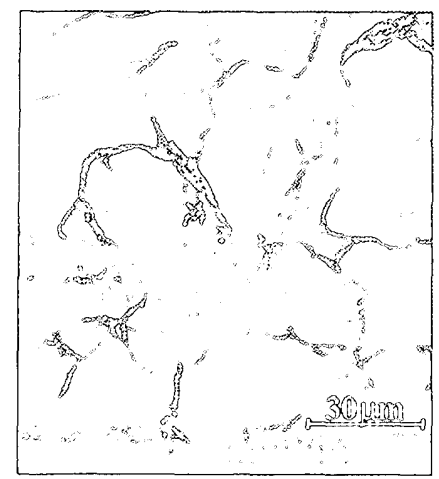

（6）破壊起点の脆性ミクロ破面 (リバー模様)

写兵一 6 実大破唗試験体の破面

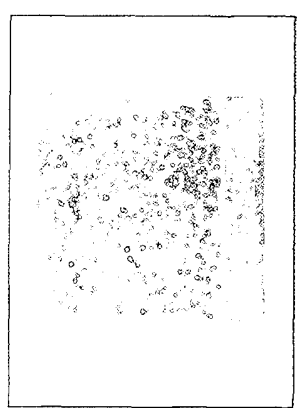

（1）マク口破面

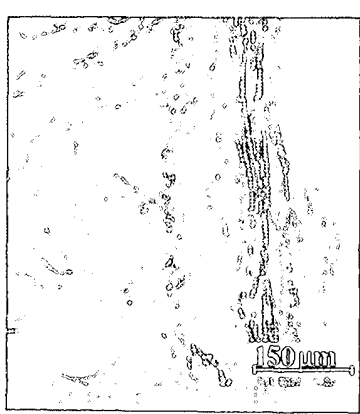

（2）ノッ千底の延性一脆性遷 移ミクロ破面

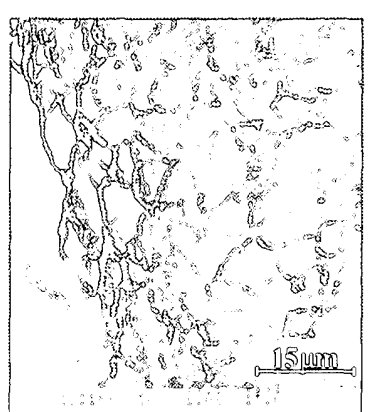

（3）ノッ千底の延性ミク口破 面（ディンプル模様）

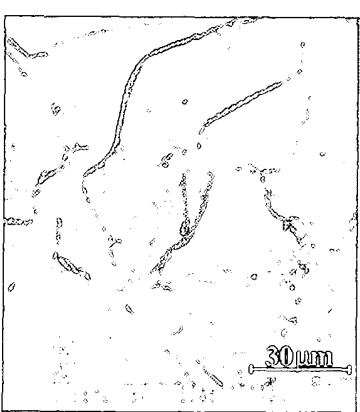

（4）ノッ千底の脆性ミク口破 面 (リバ一模様)

写真一7 実大破壊試験体から採取したシャルピー試医片の破面

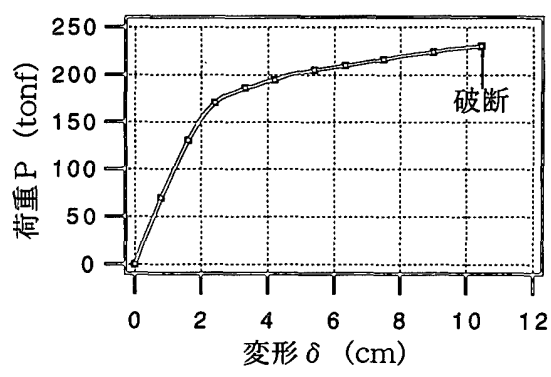

图一３寒大破壊試験の荷重と変形の関係

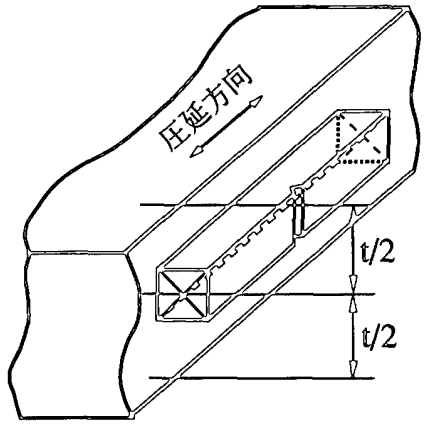

図一4 シャルピー試験片の採取位置と方向 
を見ると、ディンプル破面には数ミクロンの高低差をもった起伏が あるが，リバー破面は平坦で起伏は十分の数ミクロンである。この 起伏の状態は実大試験体破面とシャルピー破面でほぼ同じである。

\section{6. 結論}

シャルピー衝撃試験片と実大鉄骨部材の破面を比較したところ, 両者は寸法や載荷速度，破壊起点のノッチ形状が異なるにもかかわ らず，極めて類似した破面形態を呈することが破面解析により判明 した。つまり，両者ともに破壊のプロセスがひずみ集中部における 延性き裂の発生, 成長, 脆性破壊への転化といj 3 段階の共通の現 象から構成されている。しかも，同じ鋼材の場合には，延性ディン プル破面と脆性リバー破面それぞれについてシャルピー試験片と実 大部材はほぼ同じ起伏形状になっていることが確認された。このよ うな破面形成のプロセスと破面形態に関するシャルピー試験片と実 大部材の類似性は, シャルピー試験結果が実構造物の破壊性能の評 価に直接利用できる合理的な根拠を与えるものと考えられる。

今後は, シャルピー衝撃試験から得られる吸収エネルギーや脆性 破面率が実大構造物の破壊性能とどのような関係があるかについて 定量化する課題に取り組む必要がある。

\section{謝辞}

SEM 解析において東京大学総合試験所技官高橋ツ夕氏の協力を 得た。レーザー形状測定において侏キーエンス吉岡伸幸氏の協力を 得た。本論で用いた実大破壊試験データの一部は，破断総プロ「材 料・溶接と破断」分科会（主查：桑村 仁）の成果 ${ }^{20}$ から引用したも のである。関係各位に謝意を表する。

\section{参考文献}

1）東京大学工学部綕合試験所建築方面研究室：『シャルピ一試験の鉄骨破断 現象への適用に関寸る調查研究報告畫】, 1997.10

2）伊山 潤, 桑村 ·仁：シャルピー衝撃試験片の破面特性, 1997年度日本建 築学会関東支部研究報告集, pp.93-96，1998.2

3）日本建築学会：『1995年兵庫県南部地震災害調查速報』, 1995.3

4）東京大学工学部建築学科桑村研究室：『1995年兵庫県南部地震被輩調查報 告 一構造物の被害一』, 1995.5

5) Kuwamura, H. : Steel Properties Governing Structural Behaviors, in Behaviour of Steel Structures in Seismic Areas, Stessa '97 Kyoto, pp. 119.129, 1997.8

6) Charpy, M.G.: On Testing Metals by the Bending of Notched Bars (translated from Charpy's French paper by Towers, O.L. and McSweeney, S.), International Journal of Fracture, Vol. 25, No. 4, pp. $287-305,1984.8$

7) Griffith, A.A.: The Phenomena of Rupture and Flow in Solids, Philosophical Trans. of the Royal Society of London, Series A, Vol. 221, pp.163-198, 1921.3

8) Irwin, G.R. : Fracture Dynamics, in Fracturing of Metals, American Society of Metals, Cleveland, pp.147-166, 1948

9) Orowan, E. : Fracture and Strength of Solids, Reports on Progress in Physics, The Physical Society, London, Vol. 12, pp.185-232, 1949

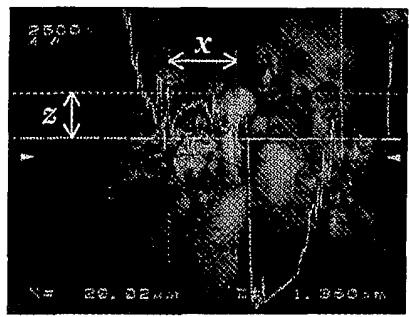

(1) 実大破壊試験体のディン プル破面 $(z=4.36 \mu \mathrm{m})$

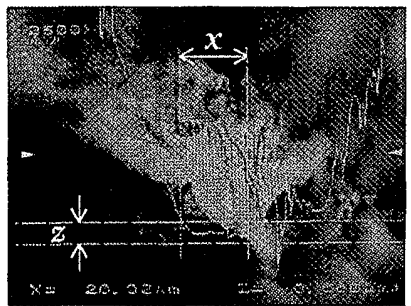

（3）奏大破壞試験体のリパー 破面 $(z=0.66 \mu \mathrm{m})$

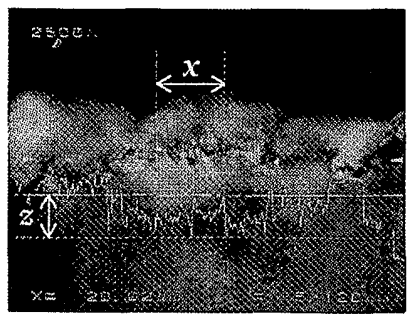

(2) シャルピー試験片のディン プル破面 $(z=5.12 \mu \mathrm{m})$

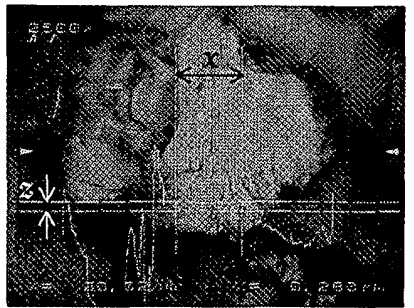

(4) シャルピー試験片のリバー 破面 $(z=0.28 \mu \mathrm{m})$
写真ー8 レーザーによる破面の起伏測定（測定長 $x=20 \mu \mathrm{m} ）$

10) Irwin, G.R.: Analysis of Stresses and Strains Near the End of a Crack Traversing a Plate, Journal of Applied Mechanics, Vol.24, pp. $361.364,1957.9$

11) Westergaard, H.M. : Bearing Pressures and Cracks, Journal of Applied Mechanics, Vol. 6, pp.A49-A53, 1939.6

12) Barsom, J.M., and Rolfe, S.T.: Fracture and Fatigue Control in Structures, 2nd Ed., Prentice-Hall, Inc., New Jersey, 1987

13）桑村 仁：鉄骨破断のとら之方，日本建築構造技術者協会 structure, No. 65, pp.27-30, 1998.1

14) Kuwamura, H. and Yamamoto, K.: Ductile Crack as Trigger of Brittle Fracture in Steel, Journal of Structural Engineering, ASCE, Vol. 123, No. 6, pp.729-735, 1997.6

15）桑村 仁：地震時における鋼構造骨組の破壊現象 一材料的側面からの 破壞原因と对策一，日本建築学会大会 PD 講演資料, pp.33-46, 1995.8

16）東京大学二学部総合試験所建築方面研究公：『SN 鋼箱形断面部材の構造 性能に関する研究 その 3 . 通しダイアフラム形式の破壊特性』, 1996.10

17）日本建築学会：「阪神・淡路大震災調查報告 建築一 3 」鉄骨造建築物一第 4 章個別事例, 1997.10

18）桑村 仁，伊山 潤，横山幸夫：高首建築における柱一梁溶接仕口の脆性 破壊，日本鋼構造協会鋼構造論文集，Vol. 4, pp.1-16, 1997.12

19）稲葉雄一郎, 伊山 潤, 桑村 仁：熱間成形及び冷間成形角形鋼管の局部 座屈後破断に関する研究, 日本建築学会大会学術講演梗概集(関東), No. 22257, pp.513-514, 1997.9

20）松井康治，伊山 潤，桑村 仁：建築構造用鋼材の脆性破壊に及ぼす寸法 効果に関する実験的研究, 1997年度日本建築学会関東支部研究報告集, pp. 97-100, 1998.2

（1997年12月 8 日原稿受理，1998年 1月30日採用沈定） 